\title{
The Effect of Lupine Seed in Broiler Diet on Animal Performance and Fatty Acids Profile of their Meat
}

\author{
Daniel MIERLITA \\ Department of Animal Science, University of Oradea, 26Magheru street, Romania; \\ *Corresponding author, e-mail: dadi.mierlita@yahoo.com \\ Bulletin UASVM Animal Science and Biotechnologies 72(2) / 2015 \\ Print ISSN 1843-5262; Electronic ISSN 1843-536X \\ DOI:10.15835/buasvmcn-asb:11375
}

\begin{abstract}
Alkaloid-free lupine seed may represent an alter native for ensuring the vegetable protein in poultry feed. Given the weight but especially the place and role of fats in maintaining consumer health, in our research we watched the effect of alkaloid free lupine seed in the diet of broiler (chicken and turkey), the animal performance and especially the effect on the fatty acids composition in the chest intramuscular fat. The experiment was conducted as a completely randomized experimental design consisting of two treatments involving a control diet consisting of corn - soybean grits (LC) and an experimental diet (LE) in which the proteins from soy grits were replaced by alkaloid free lupine flour. Two groups were organized: LC (control) - in whose diet soybean meal was used and LE protein (experimental) - in whose diet alkaloid free lupine seeds were used. In the chicken broiler diet, the protein derived from soybean meal was replaced with alkaloid free lupine flour in proportion of $30 \%$ during days 1-21 and 60\% during days 22-42 (14.0-25.7\% lupine ratio in the combined fodder structure). As for the turkey broiler, lupine seed accounted for $30 \%$ of combined fodder structure, substituting between $40 \%$ (breeding stage 0-3 weeks) and 75\% (breeding stage 15-18 weeks) of protein provided by soybean meal. Substitution of soybean meal protein in the broiler diet by introducing alkaloid free white lupine beans in broiled food has no negative effect on their bio-performance. Supplementing the broilers diet with lupine flour resulted in a decreased share of saturated fatty acids with high atherogenic potential (C14:0, C16:0, C18:0) in breast intramuscular fat and increased the share of $n-3$ series polyunsaturated fatty acids ( $\alpha$-linolenic acid especially), which at their turn decreased the n-3/n-6 series fatty acids in breast, thus increasing the nutritional quality of poultry meat, analysed in terms of impact on human consumer health.
\end{abstract}

Keywords: alkaloid-free lupine, fatty acids composition, meat, broiler.

\section{INTRODUCTION}

Using white lupine seed free of alkaloids in broiler food is justified by the high content of protein $(40.08 \% \mathrm{CP})$, but also fat $(9.70 \%$ crude fat) rich in polyunsaturated fatty acids (PUFA) consisting mainly of linoleic acid (C18 : 2n-6) and linolenic acid (C18: 3n-3) (Mierliță, 2012; 2013; 2014).

The use of white lupine seeds in proportions exceeding $25 \%$ ( $\%$ of fodder structure) does not affect the production performance of broiler (Nalle et al., 2010; Suchy et al., 2010). The use of lupine seeds in bird feeders, as the sole source of protein, is limited on the one hand by the biological value of the feed in terms of less protein content (low in amino acids limits) and on the other hand by the high content in NSP (non-starch polysaccharides) (Strakova et al., 2006; Mieczkowski et al., 2004). White lupine seeds can substitute $50 \%$ of the protein provided by soybean meal in broiler chickens if seeds are shelled or if the diet is supplemented with synthetic amino acids and enzymes (Suchy et al., 2006).

Research has primarily aimed at determining the effect of the introduction of white lupine seeds free of alkaloids in broiler chickens (chickens and turkeys) on productive parameters but mainly on 
fatty acid composition of the intramuscular fat in the chest.

\section{MATERIALS AND METHODS}

Two diets were tested: LC (control) - standard based diet soybean meals and LE (experimental) diet based on white lupine seeds free of alkaloids. In the chicken broiler diet, the protein derived from soy grits was replaced by alkaloid free lupine flour in proportion of $30 \%$ during days $1-21$ and $60 \%$ during days $22-42$ (14.0-25.7\% lupine ratio in the combined fodder structure). As for the turkey broiler, lupine seed accounted for $30 \%$ of combined fodder structure, substituting between $40 \%$ (breeding stage 0-3 weeks) and 75\% (breeding stage 15-18 weeks) of protein provided by soybean meal.

White lupine seeds (variety Energy) came from own culture made by SCDA Oradea (Mierlita, 2012). Gross chemical composition and energy value analyses were performed in our laboratory, using specific established methods (AOAC, 1996; Sibbald 1980). Lupine seeds were analysed for the content of total alkaloids as described by Ruiz (1977).

Diets were isoenergetic and isonitrogenous, including limiting amino acids (lysine and methionine). Mixed fodder was given in plenty, the amount of feed consumed being determined for each boilers lot and for each period of breeding, respectively, by means of weighing.

In order to assess the quantitative and qualitative indicators of meat production, eight broilers per each lot were randomly selected for slaughter purposes. The raw chemical composition of breast meat was determined using the Weende method.
At slaughter, samples were collected from every 150-200 g muscle tissue of the breast (skinless) and stored at $-20^{\circ} \mathrm{C}$ until laboratory analysis on the fatty acid composition of the intramuscular fat. Lipid extraction was done in a mixture of chloroform / methanol (2:1, vol/vol). Fatty acid methyl esters (FAME) were obtained from intramuscular lipids using the method described by Watkins et al. (1997), using boron trifluoride $\left(\mathrm{BF}_{3}\right)$ and methanol $(14 \% \mathrm{w} / \mathrm{w}$ USA). Methylation was carried out with sodium methoxide. Dissolution of lipids extracted in 1 $\mathrm{ml}$ of toluene was done in test tubes with teflon lid. In order to obtain FAME $0.5 \mathrm{ml}$ of sodium methoxide and $2 \mathrm{ml}$ anhydrous methanol were added, the mixture was maintained for $10 \mathrm{~min}$ at $50^{\circ} \mathrm{C}$, adding $0.1 \mathrm{ml}$ of glacial acetic acid and $5 \mathrm{~mL}$ of deionized water. To identify FAME, a gas chromatograph (GC HP 5890 Series II) with a capillary column: $30 \mathrm{~m} \times 0.53 \mathrm{~mm}$ i.d was used. The gas chromatographic operating parameters were: $140^{\circ} \mathrm{C}$ for $2 \mathrm{~min} ; 1.5^{\circ} \mathrm{C} / \mathrm{min}$ up to $200^{\circ} \mathrm{C}$ and held for $6 \mathrm{~min}$. Injector and detector flame ionization indicated temperatures $225^{\circ} \mathrm{C}$ and $260^{\circ}$ $\mathrm{C}$, respectively. FAME identification was made by their retention times with standards (not-CheckPrep., USA). Expression of fatty acids was made in percentage of the total FAME identified.

The obtained data were subjected to variance analysis by using ANOVA (Pallant, 2007). Comparisons among means were done with the Tukey test. The level of significance was established at $\mathrm{P} \leq 0.05$.

\section{RESULTS AND DISCUSSION}

Lupine beans have a higher crude protein content $(44.00 \%$ in DM), crude fat $(10.69 \%$ in DM)

Tab. 1. Gross chemical composition and energy value lupine beans (\% of DM -dry matter)

\begin{tabular}{cccc}
\hline & Mean & Max. & Min. \\
\hline Crude protein & 44.00 & 44.90 & 41.93 \\
\hline Crude fat & 10.69 & 13.27 & 9.59 \\
\hline Crude fiber & 16.10 & 17.46 & 14.31 \\
\hline $\begin{array}{c}\text { SEN (non-nitrous } \\
\text { extractables) }\end{array}$ & 24.92 & 26.51 & 22.38 \\
\hline Crude ash & 4.00 & 4.94 & 3.66 \\
\hline Mean (kcal/kg) & 3326.9 & 3482.3 & 3158.6 \\
\hline Alkaloids (mg / kg) & 110.6 & 174.4 & 96.7 \\
\hline *alculated according to Sibbald, 1980. & & &
\end{tabular}


and crude fiber (16.10\% in DM). Due to their high fat content, lupine seeds have a high energetic value (3326.9 MEAn/kg DM) (Table 1). High crude fiber content of lupine seeds was confirmed by Brenes et al. (1993). Husking white lupine seeds may increase the bioavailability of nutrients so that the nutritional value of lupine seeds could be comparable to soybean meal (Suchý et al., 2010).

Fats of lupine beans are high in long chain fatty acids, better represented by oleic acid (C18: $1 ; 40.05 \%$ of the total identified fatty acids), linoleic acid (C18: 2 n-6; 24, 81\% of the total FA identified) and $\alpha$-linolenic acid (C18:3 n-3; 8.88\% of the FA identified) (Table 2). Green and Oram (1983) set the content of lupine seeds at approx. $50 \%$ oleic acid, $22 \%$ linoleic acid and approx. $10 \%$ $\alpha$-linolenic acid; our results confirm these values.

The results obtained in these studies are consistent with those obtained in other studies (Rubio et al., 2003; Erbas et al., 2005; Sujak et al., 2006; Uzun et al., 2007; Vecerek et al., 2008) and confirm that the lupine seeds are an important source of protein for animals, and of unsaturated fatty acids, which can help improve the fatty acid composition of the meat.
The results show that when mixed fodder is properly balanced in terms of energy, protein and limiting amino acids, substituting soybean meals protein in broilers diet with alkaloid free white lupine flour has no negative effect on weight gain, the level of food use, carcass quality and meat (see Table 3). Compared with the control group, the final weight of the chickens in the experimental group was lower by approx. 4\%, feed intake was lower by approx. $2.7 \%$, feed consumption for $\mathrm{kg}$ gain in weight was higher by approx. $1.2 \%$ and the chest carcass was lower by approx. 0.3 percentage points. However the differences were not statistically assured. The introduction of lupine in broiler chickens had lowered the price of a $\mathrm{kg}$ fodder up to $18 \%$, while feed costs per $1 \mathrm{~kg}$ gain that weight dropped to $17 \%$. If the diet is balanced in amino acids (lysine, methionine, tryptophan), introduction of white lupine seeds free of alkaloids in broiler chickens (chickens and turkeys) in the amount of max. $250 \mathrm{~g} / \mathrm{kg}$ fodder does not affect their productive performance (Roth-Maier and Paulicks, 2003). Special attention should be paid to sulfur amino acids that are deficient in white

Tab. 2. Fatty acid composition of lupine seed (\% of FAME)

\begin{tabular}{cccc}
\hline Fatty acid & X mean & X min. & X max. \\
\hline C12:0 & 0.78 & 0.63 & 1.07 \\
\hline C14:0 $16: 0$ & 0.15 & 0.08 & 0.23 \\
\hline C16:1 & 6.79 & 4.30 & 11.64 \\
\hline C18:0 & 1.03 & 0.34 & 1.73 \\
\hline C18:1n-9 & 4.60 & 2.58 & 6.93 \\
\hline C18:2n-6 & 40.05 & 36.20 & 49.61 \\
\hline C18:3n-3 & 24.81 & 22.19 & 30.98 \\
\hline C20:0 & 8.88 & 6.36 & 12.14 \\
\hline C20:1n-9 & 1.25 & 0.99 & 1.69 \\
\hline C20:2n-6 & 6.57 & 6.20 & 8.07 \\
\hline C20:4 & 1.15 & 0.81 & 1.72 \\
\hline Total SFA & 3.94 & 2.83 & 4.88 \\
\hline Total MUFA & 17.51 & 8.58 & 21.56 \\
\hline Total PUFA & 47.65 & 42.74 & 59.41 \\
\hline PUFA n-6 & 34.84 & 32.19 & 49.72 \\
\hline PUFA n-3 & 25.96 & 23.00 & 32.70 \\
\hline n-6/n-3 FA & 8.88 & 6.36 & 12.14 \\
\hline
\end{tabular}

FAME = fatty acid methyl esters; FA = fatty acid; SFA = saturated fatty acid; MUFA = monounsaturated fatty acid; PUFA = polyunsaturated fatty acid. 
Tab. 3.The effect of lupine seed in broiler diet on growth performance

\begin{tabular}{cccccc}
\hline \multirow{2}{*}{ Variable } & \multicolumn{2}{c}{ Chicken broiler } & \multicolumn{2}{c}{ Turkey broiler } \\
\cline { 2 - 5 } & Lc & Ec & Lc & Et \\
\hline \multirow{2}{*}{$\begin{array}{c}\text { Body weight } \\
\text { (g) }\end{array}$} & Initial & $41.6 \pm 0.67$ & $41.9 \pm 0.49$ & $50.7 \pm 0.23$ & $50.4 \pm 0.53$ \\
\cline { 2 - 5 } & Final & $2598.7 \pm 42.9$ & $2493.8 \pm 48.16$ & $19.87 \pm 0.28^{1}$ & $19.07 \pm 0.25$ \\
\hline \multicolumn{2}{c}{ Average daily gain (g) } & 60.85 & 58.36 & 157.29 & 150.95 \\
\hline \multicolumn{2}{c}{ Feed intake (g/day) } & 108.63 & 105.49 & 419.0 & 405.9 \\
\hline \multicolumn{2}{c}{ FCR (kg feed/kg gain) } & 1.785 & 1.807 & 2.664 & 2.689 \\
\hline \multicolumn{2}{c}{ Costs feed (Ron /kg gain) } & 2.77 & 2.27 & 4.29 & 3.83 \\
\hline \multirow{2}{*}{$\begin{array}{c}\text { Slaughter yield } \\
(\%)\end{array}$} & Carcass gril & $68.65 \pm 4.73$ & $67.07 \pm 3.72$ & $72.47 \pm 0.57$ & $72.54 \pm 0.72$ \\
\cline { 2 - 5 } & Commercial & $75.69 \pm 7.31$ & $74.16 \pm 6.18$ & $74.71 \pm 0.62$ & $74.64 \pm 0.64$ \\
\hline \multirow{2}{*}{$\begin{array}{c}\text { Quality of the } \\
\text { carcass (\%) }\end{array}$} & Breast & $35.72 \pm 1.71$ & $35.43 \pm 0.43$ & $37.08 \pm 2.05$ & $36.43 \pm 0.77$ \\
\cline { 2 - 5 } & Hams + Thigh & $30.81 \pm 1.10$ & $30.72 \pm 0.84$ & $17.59 \pm 0.67$ & $18.74 \pm 0.52$ \\
\hline Lc-control group; Ec - experimental chicken group; Et - experimental turkey group; FCR - feed conversion ratio; ${ }^{1}-$ kg/turkey broiler
\end{tabular}

lupine seeds, representing only $1 / 3$ of that found in soybean meal (Nalle et al., 2010).

The negative influence of lupine is attributed to the large amounts of NSP (non-starch polysaccharides). They have a negative effect on both feed intake and use (Roth-Maier and Paulics, 2003; Steenfeldt et al., 2003).

Partial replacement of soybean with lupine flour in broilers (chicken and poultry) resulted in no significant differences ( $p>0.05)$ in the chemical composition of breast muscles. The only exception is the crude ash content which has significantly increased $(\mathrm{p}<0.01)$ in chickens compared to the control lot (Lc). Our results are in agreement with those obtained by Suchy et al. (2010), who reported that replacing soy nitrogen at a rate of up to two-thirds does not affect the protein and fat content in breast and thigh muscles, but it only increases the crude ash content in the breast. Contrary to our results, Suchy et al. (2010) found a drop in crude ash content of thigh muscle.

Intramuscular fat fatty acid profile of breast has been significantly improved by the introduction of lupine seeds in broiler diet. Thus, compared with the control group there was an increase in the share of monounsaturated fatty acids (MUFA) and especially PUFA and decrease of saturated fatty acid (SFA). Stearic acid (C18: 0), which has negative effects on the cardiovascular consumers, recorded the largest drop in the structure of chest fat in chickens which were introduced white lupine seeds (Table 4).

The largest share of PUFA is represented by the linoleic acid (LA, C18:2n-6), but the most important one, analysed in terms of impact on the consumer's health, is the share of $\alpha$-linolenic acid (ALA, C18:3n-3). Placing lupine flour in the broilers' diet caused an increase of the share of fatty acids of both the $n-6$ series and the $n-3$ series, in the breast intramuscular fat structure, which is equivalent to an improvement of their nutritional features. Thus, compared to the control group (LC), group LE, weighted LA structure of intramuscular fat increased from $54.4 \%$, while ALA share rose from $91.04 \%$. The highest increases were recorded in turkey (Mierlita, 2013). It is worth noting that the highest content of C18: 2 n- 6 (omega-6) was recorded in broilers, while broiler turkeys showed the highest concentration of C18: 3 n-3 (omega 3). These results demonstrate the superior quality of the turkey meat, from a nutritional standpoint, determined on the one hand by the content of lower fat breast meat, and on the other hand the higher content of intramuscular fatty acid Omega-3. Increasing the share of $n-3$ series polyunsaturated fatty acids in meat, as a result of including lupine flour in broilers' (chickens and poultry) diet is particularly beneficial to consumer's health, as the nutritional qualities of poultry meat (and especially of turkey) are improved.

Increasing the share of $\mathrm{n}-3 \mathrm{FA}$ and narrowing ratio n-6 / n-3 FA is beneficial for human health. However, in the case of broiler chickens ratio n-6 / n-3 was higher than that recommended by nutritionists for healthy human nutrition $4: 1$ (Nalle, 2009).

Similar studies have shown that white lupine seeds placed in diets lead to increased 
Tab. 4. Influence of lupine seed on the FA composition in breast intramuscular fat (\% of FAME)

\begin{tabular}{|c|c|c|c|c|}
\hline & \multicolumn{2}{|c|}{ Chicken broiler } & \multicolumn{2}{|c|}{ Turkey broiler } \\
\hline & Lc & Ec & Lc & Et \\
\hline Crude fat $(\%)$ & 8.61 & 8.47 & 2.85 & 2.66 \\
\hline Lauric, C12:0 & 0.12 & $0.21^{*}$ & 0.62 & $1.34^{* *}$ \\
\hline Miristic, C14:0 & 0.47 & 0.45 & 0.72 & 0.82 \\
\hline Pentadecanoic, C15:0 & 0.09 & 0.12 & 0.19 & 0.24 \\
\hline Palmitic, C16:0 & 22.60 & $19.27^{* *}$ & 36.53 & $24.66^{* *}$ \\
\hline Stearic, C18:0 & 6.58 & 5.75 & 9.09 & 9.39 \\
\hline Total SFA & 29.86 & $23.80^{* *}$ & 47.16 & $36.45^{* *}$ \\
\hline Palmitoleic, C16:1 & 3.10 & 3.50 & 8.04 & $6.73^{*}$ \\
\hline Oleic C18:1 n-9 & 29.26 & $33.10 *$ & 19.02 & $17.02^{*}$ \\
\hline Trans-vaccenic C18:1 t-11 & 0.28 & 0.23 & 0.37 & 0.26 \\
\hline Eicosenoic, C20:1 n-9 & 0.45 & 0.45 & 0.45 & $1.00^{* *}$ \\
\hline Total MUFA & 33.09 & $37.28^{* *}$ & 27.88 & 25.01* \\
\hline Linoleic, C18:2 n-6 & 22.86 & $24.09 *$ & 6.32 & $9.76^{*}$ \\
\hline Arachidonic, C20:4 n-6 & 4.04 & 3.98 & 8.59 & 9.80 \\
\hline Total PUFA n-6 & 26.90 & 28.07* & 14.91 & $19.56^{*}$ \\
\hline Linolenic, C18:3 n-3 & 1.12 & $1.56^{* *}$ & 2.79 & $5.33^{* *}$ \\
\hline Eicosapentaenoic, C20:5n-3 & 0.67 & $1.09 *$ & 1.07 & $1.89^{*}$ \\
\hline Docosapentaenoic, C22:5n-3 & 1.62 & $2.19^{*}$ & 1.95 & $4.82^{* *}$ \\
\hline Docosahexaenoic, C22:6n-3 & 0.73 & 0.78 & 1.73 & 2.30 \\
\hline Total PUFA n-3 & 4.14 & $5.62 *$ & 7.54 & $14.35^{* *}$ \\
\hline Total PUFA (n-3 + n-6) & 31.04 & $33.70 *$ & 22.45 & $33.91^{* *}$ \\
\hline Unidentified fatty acids & 2.51 & $4.63^{*}$ & 2.51 & $4.63^{*}$ \\
\hline PUFA n-6/n-3 & 6.49 & $4.99 *$ & 1.98 & $1.36^{*}$ \\
\hline
\end{tabular}

concentration of omega-3 FA (especially C18: 3n3) in poultry fat (Strakova et al., 2006). Zelenka et al. (2008) considers that supplementing the broilers' diet with fat rich in essential fatty acids provides better quality meat.

Including white lupine seeds in broiler food had positive effects on meat products resulting from the metabolism of PUFA, especially of linolenic acid: docosapentaenoic acid (DPA, C22: 5n-3) and eicosapentaenoic acid (EPA, C20: 5n-3). Their share in the structure of intramuscular fat increased by $35.2-62.6 \%$ for chickens and 47.2 $76.6 \%$ in turkey (p <0.01) (Mierlita, 2013). Our results are supported by research conducted by Nalle (2009), who demonstrated that there is a positive correlation between the level of C18: $3 n-3$ in broiler chickens and concentration of EPA and DPA in intramuscular and intra-abdominal fat.

\section{CONCLUSION}

Use of lupine seeds free of antinutritive substances in broiler diets did not affect the final weight, degree of recovery of the food or the quality of housing, instead it contributes to reduced costs for feeding birds. Lupine seeds have improved the nutritional quality of intramuscular fat in the chest, resulting in decreased weight of saturated fatty acids (in particular: C14:0, C16:0, C18:0) and increasing the share of polyunsaturated fatty acids n-3 (in particular: C18:3n-3, C20:5n-3 and C22:5n-3) and n-6 (in particular: C18:2n-6). The ratio n-6 / n-3 FA narrowed, making the meat favourable for human nutrition.

Acknowledgments. This work was supported by a grant of the Romanian National Authority for Scientific Research, CNDI-UEFISCDI, project number PN-II-IN-CI-2012-1-0257 and project number PN-II-IN-CI-2013-1-0080.

\section{REFERENCES}

1. AOAC (1996). Official methods of analysis (16th ed.). Association of Official Analytical Chemists, Inc. Arlington, Virginia, USA. 
2. Brenes A, Marquadt RR, Guenter W, Rotter BA (1993). Effect of enzyme supplementation on the nutritional value of raw, autoclaved, and dehulled lupins (Lupinus albus) in chicken diets. Poultry Sci. 72: 2281-2293.

3. Boschin G, D'Agostina A, Annicchiarico P, Arnoldi A (2008). Effect of genotype and environment on fatty acid composition of Lupinus albus L. seed. Food Chemistry 108: 600-606.

4. Boschin G, D’Agostina A, Annicchiarico P, Arnoldi A (2007). The fatty acid composition of the oil from Lupinus albus cv. Luxe as affected by environmental and agricultural factors. European Food Research and Technology 225: 769776.

5. Erbas M, Certel M, Uslu MK (2005). Some chemical properties of white lupine seeds (Lupineus albus L.). Food Chem 89: 341-345.

6. Green A G, Oram R N (1983). Variability for protein and oil quality in Lupinus albus. Anim. Feed. Sci. Technol. 9, 271282.

7. Mieczkowska A, Smulikowska S, Nguyen CV (2004). Effect of enzyme supplementation of white lupin (Lupinus albus var. Butan) - containing diets on performance, nutrient digestibility, viscosity, $\mathrm{pH}$, and passage rate of digesta in broiler chickens. J Anim Feed Sci 13: 475-486.

8. Mierlita D (2012). Studies on cultivation suitability and nutritional characterization of lupine alkaloid-free varieties. Analele Univ. din Oradea, Fascicula: Ecotox. Zootehnie, ISSN 1583-4301; vol. XIB: 501 - 507.

9. Mierlita D (2012). Raport de cercetare: Studiul eficientei cultivării și utilizării în alimentația păsărilor a unor soiuri de lupin liber de alcaloizi. http://protmed.uoradea. ro/facultate/cercetare/proiecte nationale files/web0257/ bibliografie.htm

10. Mierlita D, Popovici D (2013). Effect of partial substitution of soybean meal with lupine seeds on growth and economic efficiency of broilers. Lucrări Stiințifice-Seria Zootehnie, 59: 60-65.

11. Mierlita D (2013). Raport de cercetare: Tehnologii inovative de furajare a puilor broiler de curca bazate pe utilizarea unor surse alternative de proteine libere de substante antinutritive. http://protmed.uoradea.ro/ facultate/cercetare/proiecte_nationale_files/web0080/ index.htm

12. Mierlita D (2014). Research on determining the nutritional value of lupine grain and rapeseed meals free of antinutritive substances. Analele Univ. din Oradea, Fascicula: Ecotox. Zootehnie, ISSN 1583-4301; vol. XIIIB: 301 - 306.

13. Nalle CL, Ravindran V, Ravindran G (2010). Evaluation of Faba Beans, White Lupins and Peas as Protein Sources in Broiler Diets. International Journal of Poultry Science 9 (6): 567-573.

14. Nalle CL (2009). Nutritional Evaluation of Grain legumes for Poultry. Ph.D. Thesis. Massey University, Palmerston North, New Zealand.

15. Pallant J (2007). SPSS Survival Manual, Mc Graw Hill, Open University Press Aplicatii, http://www.allenandunwin. com/spss3/default.htm.
16. Roth-Maier DA, Paulicks BR (2003). Feeding and nutritional value of sweet blue and yellow lupin seed (Lupinus angustifolius L., Lupinus luteus L.) for broiler chicks. Arch Geflügelkd 67: 175-178.

17. Rubio LA, Brenes A, Centeno C (2003). Effects of feeding growing broiler chickens with practical diets containing sweet lupin (Lupinus angustifolius) seed meal. British Poultry Science 44: 391-397.

18. Ruiz LP Jr (1977). A rapid screening test for lupin alkaloids, New Zealand Journal of Agricultural Research, 20:1, 51-52, DOI: 10.1080/00288233.1977.10427301.

19. Sibbald IR (1980). Metabolizable energy in poultry nutrition. BioScience 30(11):736-741.

20. Steenfeldt S, Gonzalez E, Knudsen KEB (2003). Effects of inclusion with blue lupins (Lupinus angustifolius) in broiler diets and enzyme supplementation on production performance, digestibility and dietary AME content. Anim. Feed Sci. Technol. 10:185-200.

21. Straková E, Suchý P, Večerek V, Šerman V, Mas N, Jůzl M (2006). Nutritional composition of seeds of the genus Lupineus. Acta Vet Brno 75: 489-493.

22. Suchý P, Straková E, Herzig I, Steinhauser L, Vopálenský J, Kroupa L (2010). Effect of Replacing Soybean Meal with Lupin Seed-based Meal in Chicken Diet on Performance, Carcass Value and Meat Quality. Acta Vet. Brno, 79: 195202.

23. Suchy P, Strakova E, Vecerek V, Serman V, Mas N (2006). Testing of Two Varieties of Lupin Seeds as Substitutes for Soya Extracted Meal in Vegetable Diets Designed for Young Broilers. Acta Vet. Brno, 75: 495-500.

24. Sujak A, Kotlarz A, Strobel W (2006). Compositional and nutritional evaluation of several lupine seeds. Food Chem 98: 711-719.

25. Uzun B, Arslan C, Karhan M, Toker C (2007). Fat and fatty acids of white lupin (Lupinus albus L.) in comparison to sesame (Sesamum indicum L.). Food Chemistry 102: 4549.

26. Vecerek V, Suchý P, Straková E, Machácek M (2008). Nutritive composition of seeds of the lupin varieties registered in the Czech Republic. IN J.A. Palta and J.B. Berger (eds). 2008. 'Lupins for Health and Wealth' Proceedings of the $12^{\text {th }}$ International Lupin Conference, 14-18 Sept. 2008, p: 123-126, Fremantle, Western Australia. International Lupin Association, Canterbury, New Zealand.

27. Watkins BA, Shen CL, McMurtry JP, Xu H, Bain SD, Allen KGD, Seifert MF (1997). Dietary lipids modulate bone prostaglandin $\mathrm{E}_{2}$ production, insulin-like growth factor-I concentration and formation rate in chicks. J. Nutr., 127: 1084-1091.

28. Zelenka J, Schneiderova D, Mrkvicova E, Dolezal P (2008). The effect of dietary linseed oils with different fatty acid pattern on the content of fatty acids in chicken meat. Vet Med.; 53:77-85. 